\section{Pacific Entomological Survey}

ON November 2, 1932, a statement of the work and objects of the Pacific Entomological Survey was made before the Royal Entomological Society of London, as a result of which a resolution was passed unanimously inviting Dr. S. A. Neave to write and commend the work in the name of this Society, of which he later became president. On November 26 of the same year an appeal was issued in NATURE $(130,802-3 ; 1932)$, and further generous support was, despite the depression, fortheoming from various sources in Hawaii and elsewhere. Then, in 1935-37, liberal grants through the trustees of the will of the late Viscount Leverhulme and through the British Museum (Natural History) enabled Mr. E. P. Mumford, director of the Survey, to accept Sir Edward Poulton's invitation to complete the present phase of the work in the Oxford University Museum, where Sir Edward's successor, Prof. G. D. Hale Carpenter, is extending the hospitality of the Hope Department. The work of the Survey is of interest to all countries the territories of which either surround or extend into the Pacific, for, as Dr. Neave points out in the letter referred to above, "a knowledge of the fauna of all the Pacific Islands may well be of the utmost value in the more cultivated and developed ones, in that it may give a clue to the origin of many of the local pests of the latter, and thus point to opportunities for devising their biological control".

THE work of the Survey is already well advanced, and some 150 papers have been submitted for publication in Hawaii and elsewhere. It was originally proposed to prepare for publication a résumé and analysis of the findings of the Survey, and a discussion of the bearings thereof on the problems of distribution of insects in the Pacific, but it is becoming increasingly apparent as a result of the researches in Oxford that such an analysis will, to be of any value, have to take into account, not only the fauna of the islands of the Pacific, but also that of other islands. In reviewing (NATURE, 130, $797 ; 1932$ ) a manuscript copy of "Entomological Researches in the Marquesas Islands" (afterwards published in V $\mathrm{V}^{\mathrm{e}}$ Congrès International d'Entomologie, pp. 431-450, Paris, 1933), Dr. Hugh Scott referred to certain groups that are said to be absent from the Marquesas, and stated that the authors, Messrs. Mumford and Adamson, regarded these gaps in the fauna as strong evidence against the existence in past ages of extensive land areas in the Pacific, but, as Dr. Scott points out, some of these groups are also absent from the faunas of islands not of volcanic and purely oceanic origin. Furthermore, some of these groups that are thought to be absent from the Marquesas have been taken in supposedly oceanic islands elsewhere. Though Cicadas are unknown in the Marquesas, a remarkable genus has been described from Samoa, which island group Prof. Buxton considers to be oceanic. Caddisflies and may-flies, supposedly absent from the Marquesas, have been taken in Samoa as well as in the 'crypto-oceanic' Canary Islands and Madeira, and froghoppers, which were not met with by Messrs. Mumford and Adamson in the Marquesas, are known from Tonga, Samoa, the Society Islands, and Rapa. In bringing these extensive studies to a focus in Oxford, and at Farnham House Laboratory by courtesy of Dr. Thompson, Mr. Mumford and his assistants have received every assistance and cooperation from specialists throughout the world. Correspondence concerning island faunas may be addressed to the Hope Department of zoology (Entomology), University Museum, Oxford.

\section{Progress towards Internationalism}

THE October-January number of Science and Society is devoted to a discussion of the conditions of progress towards internationalism. Prof. E. Jackh, in an article on "The Changing International Relations", stresses the necessity of development into supra-national relations. Supra-national science has made possible and indeed necessary the organization of an international society. The tempo of such development, in which science shows the way, is determined by the extent to which humanity values technical civilization, science and their worldchanging effect as bursting asunder the frontiers between peoples. Prof. H. J. Fleure contributes an article on "Society and Liberty" in which he shows that society must be studied ecologically with a deep realization that no one has the whole truth; we are all seekers, and the truth is far above us all. $\mathrm{He}$ urges that it is our duty, in the name of science, to plead for freedom of conscience not only as an essential for scientific thought, but also as the only way in which in the long run society can keep in touch with the ever-flowing changes in the world. "Anthropology and racialism" is the subject of an article by J. C. Trevor, who, directing attention to some of the inherent difficulties in the consideration of problems of race, points out the danger to world peace which the accentuation of racial disparities may offer if identified with nationalistic aspira. tions.

Adrian Stephen's article on "War and Emotional Development" discusses some difficulties in a supranational authority and suggests that a hopeful line of progress lies in learning to regard countries or nations as pieces of machinery with definite functions for the promotion of human happiness rather than as idealized mothers and fathers. The application of science to political and international affairs at the present juncture is urged by C. A. Mace, in a thoughtful article "Planning Peace", to be less a matter of using specific material from the relevant social sciences than of infusing politics with some respect for the scientific spirit and the scientific point of view. Mr. Mace stresses the need for a system of publication, without fear or favour, of tested matters of fact. as essential to restore public confidence and to give intelligence to public judgment. R. H. Pender's survey of the political phases of Western Society leads him to the conclusion that any reintegration of society has to be achieved consciously 